\title{
WPLYW WARUNKU BRZEGOWEGO DIRICHLETA NA SZYBKOŚĆ I STABILNOŚĆ SYMULACJI PRĄDÓW WIROWYCH ELEKTRYCZNYM POTENCJALEM SKALARNYM
}

\author{
Przemysław Płonecki, Jacek Starzyński, Stanisław Wincenciak \\ Politechnika Warszawska, Wydział Elektryczny, Instytut Elektrotechniki Teoretycznej i Systemów Informacyjno-Pomiarowych
}

Streszczenie. Polem zastosowań prezentowanych wyników sa problemy bioelektromagnetyzmu. Matematyczny opis prądów wirowych, przy wolnozmiennych wymuszeniach elektromagnetycznych pochodzacych od ptynacego $w$ cewce pradu elektrycznego, zostat sformutowany $w$ oparciu o skalarny potencjat elektryczny. W artykule przedstawiono oddziaływanie zadawania zerowego warunku brzegowego Dirichleta na jakość i szybkość otrzymywania wyników. Szereg testów numerycznych wykazal, iż nie zawsze jest on wskazany.

Slowa kluczowe: Warunki brzegowe, skalarny potencjał elektryczny, prądy wirowe, MES

\section{IMPACT OF DIRICHLET BOUNDARY CONDITION ON CALCULATION RATE AND STABILITY DURING EDDY CURRENT MODELLING USING ELECTRIC SCALAR POTENTIAL}

\begin{abstract}
Field of presented results are bioelectromagnetic problems. Mathematical description of eddy-currents excited by external, low time-varying magnetic fields coming from the current flowing in the coil, was formulated on the basis of the electric scalar potential. This article shows effect of applies Dirichlet boundary condition to calculation rate and stability. Lots of numerical tests show that it is not always advisable.
\end{abstract}

Keywords: Boundary condition, electric scalar potential, eddy current, FEM

\section{Wstęp}

Modelowanie prądów wirowych w organizmach żywych wiąże się z wieloma trudnościami [5]. Największym wyzwaniem jest odwzorowanie struktury wewnętrznej, co powoduje, że dyskretyzacja modelu musi być wyjątkowo gęsta [2, 7]. Wykorzystanie pary potencjałów $\varphi$ i $\vec{A}$ [6] (gdzie: $\varphi$ - elektryczny potencjał skalarny [V] i $\vec{A}$ - magnetyczny potencjał wektorowy $[\mathrm{Wb} / \mathrm{m}]$ ) pozwala ograniczyć model do obszaru ciała ludzkiego. Symulacje komputerowe zostały przeprowadzone przy pomocy Metody Elementów Skończonych (MES). Głównym celem niniejszego artykułu jest przedstawienie wpływu warunku brzegowego Dirichleta na efektywność otrzymywania rozwiązania.

\section{Matematyczny opis prądów wirowych}

Bezpośrednia implementacja numeryczna równań Maxwella wiąże się z trudnościami i zwiększeniem czasu niezbędnego do otrzymania wyników symulacji komputerowej. Dla problemów bioelektromagnetyzmu uwzględnianie wszystkich zjawisk $\mathrm{z}$ dziedziny elektromagnetyzmu nie jest konieczne. Równanie różniczkowe cząstkowe, opisujące rozkład prądów wirowych $\mathrm{w}$ środowiskach słaboprzewodzących zostało wyprowadzone $\mathrm{Z}$ prawa Faradaya $\mathrm{z}$ wykorzystaniem tożsamości różniczkowej, przyjmując postać:

$$
\nabla \cdot(\gamma \nabla \varphi)=-(\nabla \gamma) \cdot \frac{\partial \vec{A}}{\partial t}-\gamma\left(\nabla \cdot \frac{\partial \vec{A}}{\partial t}\right) .
$$

Pierwszy składnik prawej strony równania (1) może być interpretowany jako pseudoźródło pola na granicach niejednorodności materiałowej. Wyznaczenie $\nabla \gamma$, którego wartość zmierza do nieskończoności zostało szczegółowo opisane w pracy [4]. Drugi składnik prawej strony równania (1) teoretycznie powinien być równy 0 , ale $\mathrm{w}$ przypadku numerycznego obliczania rozkładu wektora $\vec{A}$ uwzględnia błędy numeryczne wyznaczania rozkładu wartości $\vec{A}$, objawiające się niezerową wartością wyrażenia $\nabla \cdot \vec{A}$ w elemencie skończonym. Poszukiwaną wartość prądów wirowych opisuje wzór:

$$
\vec{J}=\gamma \vec{E}=-\gamma \nabla \varphi-\gamma \frac{\partial \vec{A}}{\partial t} .
$$

Zewnętrzne, zmienne w czasie pole magnetyczne jest źródłem prądów wirowych. W obszarze jednorodnym magnetycznie
( $\mu=\mu_{0}=$ const.), rozkład pola magnetycznego pochodzącego od cewki możemy określić używając półanalitycznego całkowania korzystając z prawa Biota-Savarta:

$$
\frac{\partial \vec{A}}{\partial t}=\frac{\mu_{0}}{4 \pi} \int_{V} \frac{\partial \vec{J}}{\partial t} \frac{1}{|\vec{r}|} d v .
$$

Ponieważ prąd elektryczny nie przepływa przez zewnętrzną powierzchnię badanego obszaru $(\vec{J} \cdot \vec{n}=0)$, możliwe jest określenie na niej fizycznie uzasadnionego warunku brzegowego Neumanna o postaci:

$$
\gamma \frac{\partial \varphi}{\partial n}=-\gamma \frac{\partial A_{n}}{\partial t},
$$

gdzie $\vec{n}$ wektor prostopadły do powierzchni zewnętrznej obszaru przewodzącego.

Niejednoznaczność definicji potencjałów $\varphi, \vec{A}$ można usunąć przez zastosowanie kalibracji $\vec{A}$ i określenie potencjału odniesienia $\mathrm{w}$ postaci warunku brzegowego Dirichleta. Ten warunek zmniejsza zbiór dopuszczalnych rozwiązań i powinien mieć wpływ na czas niezbędny do rozwiązania układu równań liniowych.

\section{Zadania testowe}

Przedstawiony model numeryczny został zaimplementowany $\mathrm{w}$ języku programowania $\mathrm{C}++\mathrm{z}$ wykorzystaniem bibliotek wspomagających rozwiązywanie równań różniczkowych cząstkowych Diffpack [3]. Umożliwia również zadanie zerowego warunku brzegowego Dirichleta. Jego uwzględnienie nie jest konieczne do osiągnięcia stabilności otrzymania poprawnego rozwiązania układu równań liniowych.

Do zagadnień testowych wykorzystano rzeczywiste, niejednorodne pole $\vec{A}$, pochodzace od cewki.

Teoretycznie pominięcie drugiego składnika prawej strony równania (1) nie powinno nieść ze sobą żadnych konsekwencji, gdyż wykorzystane potencjały ( $\varphi$ i $\vec{A}$ ) nie mogą mieć wpływu na wartość pola, a służą jedynie efektywniejszemu otrzymywaniu poszukiwanych rzeczywistych wartości fizycznych. Natomiast badania wykazały, że już na poziomie pojedynczego elementu nie zachodzi wtedy równość:

$$
\oint_{S} \gamma \frac{\partial \varphi}{\partial n} d s=\oint_{S}-\gamma \frac{\partial A_{n}}{\partial t} d s=0 .
$$

Wyniki badań przeprowadzono zarówno na prostych bryłach geometrycznych jak i skomplikowanych modelach ciała człowieka 
(patrz rys. 1). Liczby iteracji niezbędnych do otrzymania wyników symulacji z zadaną dokładnością przedstawia (tabela 1).
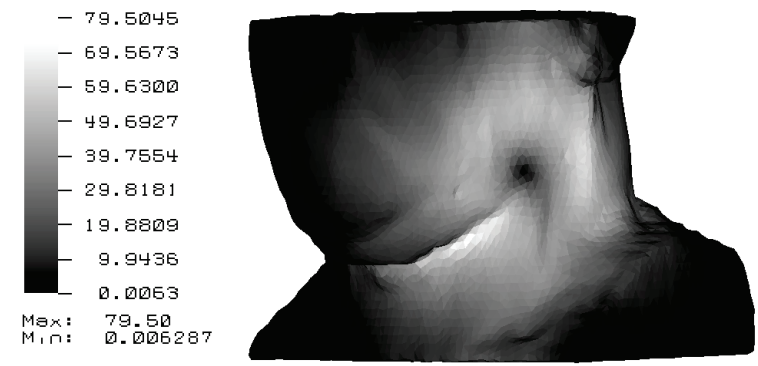

Rys. 1. Rozklad amplitudy modutu wektora gęstości pradów wirowych w modelu szyi

Tabela 1. Porównanie liczby iteracji niezbędnych do otrzymania wyników z zadanq doktadnościa z i bez uwzględnienia zerowego warunku brzegowego Dirichleta otrzymanych metoda BiCGStab (ang. BiConjugate Gradient Stabilized method) [3]

\begin{tabular}{|c|c|c|}
\cline { 2 - 3 } \multicolumn{1}{|c|}{} & $\begin{array}{c}\text { Bez zerowego warunku } \\
\text { brzegowego Dirichleta }\end{array}$ & $\begin{array}{c}\text { Z zerowym warunkiem } \\
\text { brzegowym Dirichleta }\end{array}$ \\
\hline \multicolumn{3}{|c|}{ Model kuli - 22 tys. elementów } \\
\hline Liczba iteracji & $\mathbf{5 7}$ & $\mathbf{7 7}$ \\
\hline \multicolumn{3}{|c|}{ Model walca - 36 tys. elementów } \\
\hline Liczba iteracji & $\mathbf{8 0}$ & $\mathbf{8 8}$ \\
\hline Model walca w wydrążonym walcu - 33 tys. elementów \\
\hline Liczba iteracji & $\mathbf{6 2}$ \\
\hline Model niejednorodnego walca - 35 tys. elementów \\
\hline Liczba iteracji & $\mathbf{6 8}$ \\
\hline \multicolumn{3}{|c|}{ Model kolana - 935 tys. elementów } \\
\hline Liczba iteracji & $\mathbf{4 3 1}$ & $\mathbf{7 6 7}$ \\
\hline \multicolumn{3}{|c|}{ Model szyi - 635 tys. elementów } \\
\hline Liczba iteracji & $\mathbf{2 3 0}$ \\
\hline
\end{tabular}

\section{Wnioski}

W przypadku zadania dobrze sformułowanego uwzględniającego błędy numerycznego wyznaczania $\nabla \cdot \vec{A}$ w elemencie skończonym, uwzględnianie zerowego warunku brzegowego Dirichleta jest zbędne, ponieważ niepotrzebnie zwiększa czas konieczny do otrzymania rozwiązania układu równań liniowych.

W rozpatrywanym zagadnieniu prądów wirowych wartość potencjału $\varphi \mathrm{w}$ węźle nie niesie ze sobą informacji o fizyce zagadnienia; determinuje ją dopiero wartość gradientu potencjału, $\nabla \varphi$. Wprowadzenie zerowego warunku brzegowego Dirichleta skutkuje tym, iż poszukiwane rozwiązanie $\varphi$ musi zostać dopasowane [1] we wszystkich węzłach siatki do wartości odniesienia, co zwiększa czas rozwiązania układu równań. Mający sens fizyczny gradient $\nabla \varphi$ posiada tę samą wartość dla wielu funkcji $\varphi$, i dlatego dogodne rozwiązanie jest zwykle znajdowane szybciej przy braku dodatkowych ograniczeń.

\section{Literatura}

[1] Demenko A.: Obwodowe modele trójwymiarowych układów $z$ polem elektromagnetycznym. IC-SPETO 2003, Gliwice-Niedzica 28-31.05.2003.

[2] Gjonaj E., Bartsch M., Clemens M., Schupp S., Weiland T.: High-Resolution Human Anatomy Models for Advanced Electromagnetic Field Computations, IEEE Transactions on Magnetics, vol. 38, no. 2, March 2002.

[3] Langtangen H. P.: Computational Partial Differential Equations. Numerical Methods and Diffpack Programming, Springer Verlog, Berlin-New York, 1999.

[4] Płonecki P., Sawicki B., Wincenciak S.: Modelowanie pradów wirowych $w$ środowiskach staboprzewodzacych przy wykorzystaniu skalarnego potencjalu elektrycznego, Prace Instytutu Elektrotechniki, nr 236/2008, str. 129 - 142.

[5] Siauve N., Scorretti R., Burais N., Nicolas L., Nicolas A.: Electromagnetic fields and human body: a new challange for the electromagnetic field computation, COMPEL, Vol. 22 No. 3, 2003.

[6] Stuchly M. A., Dawson T. W.: Human Organ and Tissue Induced Currents by $60 \mathrm{~Hz}$ Electric And Magnetic Fields, Proceedings - 19th International Conference - IEEE/EMBS, vol. 6, 30 Oct.-2 Nov. 1997, pp. 2464-2467.

[7] Zienkiewicz O. C.: The Finite Element Method, McGraw Hill, Meidenhead, 1977.

Mgr inż. Przemysław Plonecki
e-mail: ploneckp@iem.pw.edu.pl

Przemysław Płonecki urodził się w 1980 roku. Tytuł magistra inżyniera uzyskał w 2004 roku na Wydziale

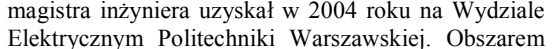
zainteresowań naukowych są zagadnienia związane $\mathrm{z}$ teoria pola elektromagnetycznego i metodami numerycznymi. Obecnie przygotowuje rozprawę doktorską dotyczącą modelowania prądów wirowych w środowiskach słaboprzewodzących na tym wydziale.

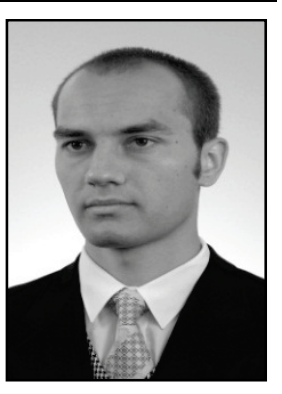

Prof. ndzw. dr hab. inż. Jacek Starzyński e-mail: jstar@ee.pw.edu.pl

Jacek Starzyński urodził się w Warszawie w 1962 r. Otrzymał tytuł magistra, oraz stopnie doktora i doktora habilitowanego na Politechnice Warszawskie odpowiednio w 1986, 1995 i 2009 roku. Aktualniejest profesorem elektrotechniki w Instytucie Elektrotechniki Teoretycznej i Systemów InformacyjnoPomiarowych, Politechniki Warszawskiej. W swojej pracy naukowej zajmuje się polem elektromagnetycznym, EMC, metodami optymalizacji oraz metodami numerycznymi. Kieruje Zakładem Wysokich Napięć i Kompatybilności Elektromagnetycznej.

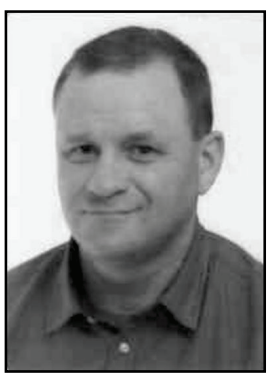

Prof. dr hab. inż. Stanisław Wincenciak

e-mail: prorektor.rozwoj@rekt.pw.edu.pl

Stanisław Wincenciak urodził się w 1949 roku. Uzyskał tytuły magistra inżyniera, doktora, doktora habilitowanego na Wydziale Elektrycznym Politechniki Warszawskiej odpowiednio w 1973, 1979 i 1991 roku. Obecnie jest profesorem na Wydziale Elektrycznym w Instytucie Elektrotechniki Teoretycznej i Systemów Informacyjno-Pomiarowych Politechniki Warszawskiej. Przedmiotem zainteresowań naukowych są obszary związane $\mathrm{z}$ teoria pola elektromagnetycznego, metodami numerycznymi i teorią optymalizacji. Obecnie pełni funkcję Prorektora ds. Rozwoju Politechniki Warszawskiej.

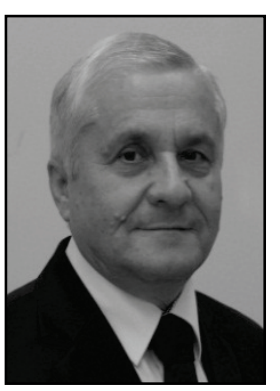

Artykuł recenzowany

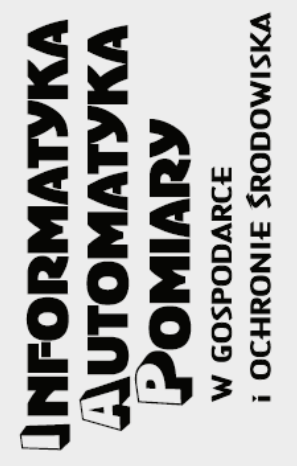

Zapraszamy na naszą stronę internetową: WWW . IAPGOS . PI

gdzie znajdziecie Państwo:

- informacje nt. zamieszczania reklam,

- wykaz prac opublikowanych w latach 2011 i 2012,

- procedurę recenzowania,

- wykaz recenzentów prac opublikowanych w poprzednich latach,

- aktualną formatkę artykułu oraz druk recenzji,

- dostęp on-line do artykułów (już wkrótce). 